\title{
Insertion/deletion polymorphism in the angiotensin-I-converting enzyme gene is associated with coronary heart disease in IDDM patients with diabetic nephropathy
}

\author{
L. Tarnow ${ }^{1}$, F. Cambien ${ }^{2}$, P. Rossing ${ }^{1}$, F. S. Nielsen ${ }^{1}$, B. V. Hansen ${ }^{1}$, L. Lecerf ${ }^{2}$, O. Poirier ${ }^{2}$, S. Danilov ${ }^{3}$, S. Boelskifte, \\ K. Borch-Johnsen ${ }^{5}$, H.-H. Parving ${ }^{1}$ \\ ${ }^{1}$ Steno Diabetes Center, Gentofte, Denmark \\ ${ }^{2}$ INSERM SC7, Paris, France \\ ${ }^{3}$ INSERM U367, Paris, France \\ ${ }^{4}$ UNI-C, Aarhus, Denmark \\ ${ }^{5}$ Glostrup Hospital, University of Copenhagen, Denmark
}

\begin{abstract}
Summary Insulin-dependent diabetic (IDDM) patients with diabetic nephropathy have a highly increased morbidity and mortality from coronary heart disease. An insertion (I) /deletion (D) polymorphism in the angiotensin-I-converting enzyme (ACE) gene has been shown to be associated with coronary heart disease. Therefore, we have investigated the role of this ACE/ID polymorphism in 198 IDDM patients with diabetic nephropathy and 190 normoalbuminuric IDDM patients. The prevalence of myocardial infarction and other coronary heart disease was significantly elevated in patients with nephropathy, $19 \%(38 / 198)$ vs $8 \%(15 / 190), p<0.001$. In the nephropathic group 12 of 63 (19\%), 23 of 95 (24\%), and 3 of $40(7.5 \%)$ patients with the DD, ID and II genotypes, respectively had a history of coronary heart disease, II vs DD and ID, $p<0.05$ when compared to nephropathic patients without coronary heart disease. Multiple logistic regression analysis of the risk factors associated with coronary heart disease in univariate analysis revealed that the II geno-
\end{abstract}

type acts as an independent protective factor against coronary heart disease, odds ratio II/DD + ID 0.27 (95\% confidence interval $0.07-0.97, p<0.05$ ). There was no difference in genotype or allele frequency (D/I) between patients with and without nephropathy, $0.56 / 0.44$ in both groups, but plasma ACE concentration was elevated in patients with nephropathy $609(151-1504) \mathrm{ng} / \mathrm{ml}$ as compared to patients with normoalbuminuria, $428(55-1630) \mathrm{ng} / \mathrm{ml}, p<0.001$. We suggest that ACE/ID polymorphism may influence the frequency of life-threatening cardiac complications in IDDM patients suffering from diabetic nephropathy, a condition characterized by increased plasma ACE concentration. [Diabetologia (1995) 38: 798-803]

Key words Plasma angiotensin converting enzyme, angiotensin-I-converting enzyme gene, coronary heart disease, diabetic nephropathy, insulin-dependent diabetes mellitus.
Approximately $30-40 \%$ of all insulin-dependent diabetic (IDDM) patients develop diabetic nephropathy [1]. The excess mortality in diabetic nephropathy is

Received: 10 October 1994 and in revised form: 20 December 1994

Corresponding author: Dr. L. Tarnow, Steno Diabetes Center, Niels Steensens Vej 2, DK-2820 Gentofte, Denmark

Abbreviations: IDDM, Insulin-dependent diabetes mellitus; ACE; angiotensin-I-converting enzyme; ACE/ID gene, insertion/deletion polymorphism in the angiotensin-I-converting enzyme gene; CHD, coronary heart disease.; PCR, polymerase chain reaction. mainly due to end stage renal failure and cardiovascular disease [2]. The relative mortality from cardiovascular disease is on average increased 40 -fold in IDDM patients with nephropathy compared to the general population [2]. This increase is highest (186fold) among young (25 to 35 years) nephropathic patients [2]. Abnormalities in well-established cardiovascular risk factors (e.g. arterial hypertension, dyslipidaemia, smoking, obesity, fibrinolytic activity, and platelet function) cannot alone account for this finding [3]. IDDM patients with abnormal albumin excretion have increased plasma angiotensin-I-converting enzyme (ACE) concentration $[4,5]$. Recent studies have demonstrated that an insertion (I)/deletion (D) 
Table 1. Clinical characteristics of 198 IDDM patients with diabetic nephropathy and 190 IDDM patients with normoalbuminuria

\begin{tabular}{|c|c|c|c|}
\hline & $\begin{array}{l}\text { Nephropathy } \\
(n=198)\end{array}$ & $\begin{array}{l}\text { Normoalbuminuria } \\
(n=190)\end{array}$ & $p$-value \\
\hline Sex (male/female) & $121 / 77$ & $118 / 72$ & NS \\
\hline $\mathrm{Age}^{\mathrm{a}}$ (years) & $40.9 \pm 9.6$ & $42.7 \pm 10.2$ & NS \\
\hline Duration of diabetes ${ }^{\mathrm{a}}$ (years) & $26.7 \pm 7.9$ & $25.8 \pm 8.5$ & NS \\
\hline Body mass index $\left(\mathrm{kg} / \mathrm{m}^{2}\right)$ & $24.0 \pm 3.3$ & $23.6 \pm 2.5$ & NS \\
\hline $\mathrm{HbA}_{1 \mathrm{c}}{ }^{\mathrm{a}}(\%)$ & $9.6 \pm 1.5$ & $8.5 \pm 1.1$ & $<0.001$ \\
\hline Serum creatinine ${ }^{\mathrm{b}}(\mu \mathrm{mol} / \mathrm{l})$ & $103(54-684)$ & $76(40-116)$ & $<0.001$ \\
\hline Systolic blood pressure ${ }^{\mathrm{a}}(\mathrm{mm} \mathrm{Hg})$ & $151 \pm 23$ & $132 \pm 18$ & $<0.001$ \\
\hline Diastolic blood pressure ${ }^{\mathrm{a}}(\mathrm{mm} \mathrm{Hg})$ & $86 \pm 13$ & $76 \pm 10$ & $<0.001$ \\
\hline Prevalence of antihypertensive treatment (\%) & $76 \%$ & $12 \%$ & $<0.001$ \\
\hline Serum total-cholesterol ${ }^{a}(\mathrm{mmol} / \mathrm{l})$ & $5.6 \pm 1.2$ & $4.8 \pm 0.9$ & $<0.001$ \\
\hline Serum HDL-cholesterol ${ }^{\mathrm{a}}(\mathrm{mmol} / \mathrm{l})$ & $1.46 \pm 0.53$ & $1.56 \pm 0.51$ & $=0.07$ \\
\hline
\end{tabular}

a Mean $\pm \mathrm{SD} ;{ }^{\mathrm{b}}$ Median (range);

c Some patients with previously persistent albuminuria receiving antihypertensive medication had a UAE $<300 \mathrm{mg} / 24 \mathrm{~h}$

polymorphism of the ACE gene (ACE/ID) is strongly associated with the level of circulating ACE and risk of myocardial infarction and severe coronary heart disease (CHD) in non-diabetic subjects and non-insulin-dependent diabetic (NIDDM) patients [6-8]. Furthermore, the ACE/ID polymorphism seems to be a potent risk factor of hypertrophic or ischaemic or idiopathic dilated cardiomyopathy and sudden death $[9,10]$. Therefore, we have investigated the ACE/ID polymorphism in IDDM patients with and without diabetic nephropathy and with and without CHD.

\section{Subjects and methods}

Patients. We examined the records of all albuminuric patients attending the outpatient clinic at Steno Diabetes Center in 1993, who had IDDM and diabetic nephropathy and had their glomerular filtration rate measured during the same year. A total of 242 Caucasian patients more than 18 years of age were identified and invited to participate in the study. Two hundred patients $(83 \%)$ accepted the invitation and were enrolled. ACE genotyping was performed in 198 patients (Table 1). No additional exclusion criteria was applied. Diabetic nephropathy was diagnosed clinically based on the following criteria: persistent albuminuria greater than $300 \mathrm{mg} / 24 \mathrm{~h}$ in at least two out of three consecutive 24-h urine collections, presence of retinopathy and no clinical or laboratory evidence of kidney or renal tract disease other than diabetic glomerulosclerosis [11].

A total of 201 previously normoalbuminuric (urinary albumin excretion rate $\leq 30 \mathrm{mg} / 24 \mathrm{~h}$ ) IDDM patients matched for sex, age and duration of diabetes were recruited from our outpatient clinic (Table 1). At baseline all patients had their urinary albumin excretion rate measured. Eighteen patients had urinary albumin excretion between $30-300 \mathrm{mg} / 24 \mathrm{~h}$; they were asked to collect three additional urine samples and in ten patients persisting microalbuminuria was detected. ACE genotyping was performed in 190 patients with persisting normoalbuminuria.
All patients had been dependent on insulin treatment from the time of diagnosis and received at least two daily injections of insulin. The experimental design was approved by the local ethical committee, and all patients gave their informed consent.

Methods. Investigations were performed in the morning after an overnight fast. Of the nephropathic patients $24 \%$ received no antihypertensive treatment vs $88 \%$ of normoalbuminuric patients. All the remaining patients were asked to stop their antihypertensive and diuretic treatment 8 days before examination in order to obtain valid results for plasma-ACE concentration. Sixty-nine ( $46 \%$ ) vs $9(39 \%)$ patients with and without nephropathy did not want to stop their antihypertensive treatment. Plasma ACE levels were determined by an Elisa method using a sandwich combination of monoclonal and polyclonal antibodies [12, Danilov et al. unpublished data] in 129 patients with nephropathy and 181 normoalbuminuric patients.

Lymphocytes were isolated from peripheral blood and DNA was prepared by standard techniques [13]. Polymerase chain reaction (PCR) was used to detect the two alleles of the insertion/deletion polymorphism. DNA was amplified using primers and PCR cycling conditions as described previously [14]. Subjects were classified, according to the presence or absence of a 287 base pair insertion in intron 16 of the ACE gene, as homozygous II,DD or heterozygous for insertion/deletion ID.

Patients were interviewed with the World Health Organization (WHO) cardiovascular questionnaire [15]. A 12-lead electrocardiogram (ECG) was recorded and subsequently coded independently by two trained observers, who were blinded to the clinical status of the patients, using the Minnesota Rating Scale [16]. CHD was diagnosed if ECG showed signs of probable myocardial infarction (Minnesota Rating Scale 1.1-2) or possible myocardial ischaemia (Minnesota Rating Scale 1.3, $4.1-4,5.1-3$ or 7.1 ), or if patients reported a history either of angina pectoris, defined in accordance to Rose [17], or of myocardial infarction according to WHO criteria [15] and validated by hospital records.

Urinary albumin concentration was determined by enzyme immunoassay [18] from 24-h urine collections. Arterial blood pressure was measured twice and averaged, on the right arm, after at least $10 \mathrm{~min}$ rest in the supine position. The measurements were performed with a Hawksley random zero sphyg- 
Table 2. Clinical characteristics of 198 nephropathie IDDM patients with and without CHD

\begin{tabular}{|c|c|c|c|}
\hline & $\begin{array}{l}\text { Nephropathy with CHD } \\
(n=38)\end{array}$ & $\begin{array}{l}\text { Nephropathy without CHD } \\
(n=160)\end{array}$ & $p$-value \\
\hline Sex (men/women) & $21 / 17$ & $100 / 60$ & NS \\
\hline $\mathrm{Age}^{\mathrm{a}}$ (years) & $45.1 \pm 9.7$ & $40.0 \pm 9.3$ & $<0.003$ \\
\hline Duration of diabetes ${ }^{\mathbf{a}}$ (years) & $29.3 \pm 8.9$ & $26.1 \pm 7.6$ & $<0.03$ \\
\hline Body mass index $\left(\mathrm{kg} / \mathrm{m}^{\mathrm{a}}\right)$ & $24.1 \pm 3.9$ & $24.0 \pm 3.1$ & NS \\
\hline $\mathrm{HbA}_{1 \mathrm{c}}{ }^{\mathrm{a}}(\%)$ & $9.9 \pm 1.7$ & $9.5 \pm 1.5$ & NS \\
\hline Smokers (\%) & $32 \%$ & $54 \%$ & $<0.01$ \\
\hline Urinary albumin excretion rate ${ }^{b}(\mathrm{mg} / 24 \mathrm{~h})^{c}$ & $911(94-8824)$ & $792(16-14545)$ & NS \\
\hline Serum creatinine $\mathrm{e}^{\mathrm{b}}(\mu \mathrm{mol} / \mathrm{l})$ & $127(73-684)$ & $96(54-403)$ & $<0.001$ \\
\hline Systolic blood pressure ${ }^{\mathrm{a}}(\mathrm{mm} \mathrm{Hg})$ & $160 \pm 23$ & $150 \pm 22$ & $<0.005$ \\
\hline Diastolic blood pressure ${ }^{\mathrm{a}}(\mathrm{mm} \mathrm{Hg})$ & $86 \pm 12$ & $86 \pm 13$ & NS \\
\hline Prevalence of antihypertensive treatment (\%) & $95 \%$ & $72 \%$ & $<0.003$ \\
\hline Serum total-cholesterol ${ }^{\mathrm{a}}(\mathrm{mmol} / \mathrm{l})$ & $6.1 \pm 1.4$ & $5.5 \pm 1.2$ & $<0.02$ \\
\hline Serum HDL-cholesterol ${ }^{\mathrm{a}}(\mathrm{mmol} / \mathrm{l})$ & $1.39 \pm 0.45$ & $1.48 \pm 0.55$ & NS \\
\hline Serum triglycerides ${ }^{b}(\mathrm{mmol} / \mathrm{l})$ & $1.44(0.74-5.07)$ & $1.19(0.31-9.87)$ & $<0.01$ \\
\hline
\end{tabular}

${ }^{\mathrm{a}}$ Mean $\pm \mathrm{SD} ;{ }^{\mathrm{b}}$ Median (range); ${ }^{\mathrm{c}}$ Some patients with previously persistent albuminuria receiving antihypertensive medication had a UAE $<300 \mathrm{mg} / 24 \mathrm{~h}$

momanometer (Hawksley \& Sons Ltd, Lancing, Sussex, UK) and appropriate cuff size. Diastolic blood pressure was recorded at the disappearance of Korotkoff sounds (phase V). Retinopathy was assessed by fundus photography after pupillary dilatation and graded: nil, simplex or proliferative diabetic retinopathy.

Body mass index (BMI) was calculated as weight $(\mathrm{kg}) /$ height $(\mathrm{m})^{2}$. From venous blood samples serum cholesterol and triglycerides were determined enzymatically using CHOD-PAP and GPO-PAP reagents from Boehringer-Mannheim GmbH (Mannheim, Germany). High-density lipoprotein (HDL)-cholesterol was determined after precipitation of apolipoprotein $\mathrm{B}$ containing lipoprotein with phosphotungstic acid [19]. Haemoglobin $\mathrm{A}_{1 \mathrm{c}}\left(\mathrm{HbA}_{1 \mathrm{c}}\right)$ was measured by high performance liquid chromatography (DIAMAT Analyzer, Bio-Rad, Hercules, Calif., USA) (normal range in our laboratory is $4.1-6.1 \%$ ). Serum-creatinine concentration was assessed by a kinetic Jaffe' method. Smokers (present and former) were defined as persons smoking more than one cigarette/cigar/pipe per day, all others being classified as non-smokers.

\section{Statistical analysis}

Urinary albumin excretion rate, serum creatinine, serum-triglyceride and plasma ACE were non-normally distributed and values are given as medians (range), all other values are given as means $\pm \mathbf{S D}$.

For normally distributed variables comparison between groups was performed by an unpaired Student's $t$-test or analysis of variance (ANOVA). In non-normally distributed continuous variables a Mann-Whitney U-test or Kruskal-Wallis test were used for comparison between groups.

A chi-square test was used to compare the distribution of ACE genotypes and alleles in diabetic patients and control subjects, and was also used for comparison between groups of non-continous variables. Allele frequencies were estimated by the gene counting method and Hardy-Weinberg equilibrium was checked by a chi-square test.

Multiple logistic regression analysis was performed introducing all variables showing significant association with $\mathrm{CHD}$ in the univariate analyses $(p \leq 0.05)$ (Table 2). Calculations were performed with commercially available programs, Stat- graphics (STSC, Rockville, Md., USA) and Statistical Analysis System (SAS, Cary, NC., USA).

\section{Results}

The group of patients with nephropathy and the normoalbuminuric group were well-matched with regard to sex, age and duration of diabetes. Clinical data of all patients are shown in Table 1. Patients with nephropathy had elevated systolic and diastolic blood pressure, raised serum creatinine and $\mathrm{HbA}_{1 \mathrm{c}}$ in addition to increased total-cholesterol and triglycerides as compared to patients with normoalbuminuria $(p<0.001)$. Nephropathic patients had a higher prevalence of proliferative retinopathy $(137(69 \%))$ compared to the normoalbuminuric group (18 $(10 \%))(p<0.001)$. There was no difference between the ACE genotype distribution in IDDM patients with diabetic nephropathy and IDDM patients with normoalbuminuria. The distribution of ACE genotypes in diabetic patients and control subjects were in Hardy-Weinberg equilibrium (NS). Plasma ACE levels were 597 (130-1630) ng/ml, 489 (122$1625) \mathrm{ng} / \mathrm{ml}$ and $391(55-1285) \mathrm{ng} / \mathrm{ml}$ in patients with $\mathrm{DD}, \mathrm{ID}$ and II genotype respectively, $p<0.001$. Patients with nephropathy had a higher plasma $A C E$ concentration, $609(151-1504) \mathrm{ng} / \mathrm{ml}$ as compared to normoalbuminuric patients, 428 (55-1630) ng/ml, $p<0.001$. Since only 14 out of 38 patients with CHD and nephropathy stopped their antihypertensive medication we did not investigate variation in plasma ACE concentration according to the presence of CHD.

The prevalence of myocardial infarction and other coronary heart disease was significantly elevated in patients with nephropathy, $19 \%(38 / 198)$ vs $8 \%(15 /$ $190), p<0.001$. Seventeen of 198 patients with ne- 
phropathy vs 6 of 190 normoalbuminuric patients had either ECG signs or a verified history of myocardial infarction.

Among patients with nephropathy (Table 2), those patients suffering from CHD were older $(p<0.003)$ and had a longer duration of diabetes $(p<0.03)$ as compared to patients without CHD. In addition, patients with nephropathy and CHD had elevated systolic blood pressure $(p=0.005)$, increased serum creatinine $(p<0.001)$ and raised total-cholesterol $(p<0.02)$ and triglycerides $(p<0.01)$. More nephropathic patients with CHD received antihypertensive medication but at the time of investigation they smoked less tobacco than nephropathic patients without CHD $(p<0.01)$.

Dependence between CHD status and the three genotypes in nephropathic patients was $p=0.08$ by chi-square test. This revealed a tendency to fewer cases than expected of CHD in patients with the II genotype. In patients with nephropathy the frequency of myocardial infarction and other coronary heart disease was lower in patients with the II genotype as compared to the two other genotypes (DD and ID) $(p=0.04$, Table 3$)$. In the nephropathic group there was no difference between genotypes (DD, ID and II) regarding sex, age, duration of diabetes, BMI, blood pressure, urinary albumin excretion rate, creatinine, $\mathrm{HbA}_{1}$, serum lipids or smoking habits. Normoalbuminuric patients with the DD-genotype had lower diastolic blood pressure $(72 \pm 10 \mathrm{~mm} \mathrm{Hg})$ as compared to the normoalbuminuric ID- $(79 \pm 9 \mathrm{~mm}$ $\mathrm{Hg})$ and II-genotypes $(76 \pm 11 \mathrm{~mm} \mathrm{Hg})(p<0.001)$ but were otherwise similar to the two other genotypes, regarding investigated cardiovascular risk factors.

Multiple logistic regression analysis of the risk factors associated with CHD in univariate analysis revealed that the II genotype acts as an independent protective factor for $\mathrm{CHD}$, odds ratio II/DD + ID was 0.27 (95\% confidence interval: $0.07-0.97$, $p<0.05$ ) (Table 4).

The distribution of ACE-genotypes was not related to the presence of CHD in patients with normoalbuminuria.

\section{Discussion}

In our cross-sectional case control study of Caucasian male and female IDDM patients, aged 21-73 years we found that the prevalence of CHD was more than twice as high in patients with diabetic nephropathy as compared to patients with normoalbuminuria.

This finding cannot be attributed to the ACE/ID polymorphism, since the ACE/ID genotype distribution was similar in the two groups. But the observed elevation in plasma ACE concentration among patients with nephropathy, and especially among pa-
Table 3. Distribution of ACE/ID genotypes in 198 nephropathic IDDM patients with and without CHD

\begin{tabular}{lll}
\hline $\begin{array}{l}\text { Genotype/ } \\
\text { allele }\end{array}$ & $\begin{array}{l}\text { Nephropathic IDDM } \\
\text { patients with CHD } \\
(n=38)\end{array}$ & $\begin{array}{l}\text { Nephropathic IDDM } \\
\text { patients without CHD } \\
(n=160)\end{array}$ \\
\hline DD & $12(32 \%)$ & $51(32 \%)$ \\
ID & $23(61 \%)$ & $72(45 \%)$ \\
II & $3(8 \%)$ & $37(23 \%)$ \\
D-allele & 0.62 & 0.54 \\
I-allele & 0.38 & 0.46 \\
\hline
\end{tabular}

a II vs $\mathrm{DD}+\mathrm{ID} ; p=0.04$

Table 4. Logistic regression analysis of the cardiovascular risk factors associated with CHD in univariate analysis

\begin{tabular}{llll}
\hline $\begin{array}{l}\text { Cardiovascular } \\
\text { risk factor }\end{array}$ & \multicolumn{3}{l}{$\begin{array}{l}\text { IDDM patients with nephropathy } \\
(n=198)\end{array}$} \\
\cline { 2 - 4 } & Odds ratio & $95 \% \mathrm{CI}$ & $p$-value \\
\hline $\begin{array}{l}\text { Age }(\Delta 5 \text { years }) \\
\begin{array}{l}\text { Total cholesterol } \\
(\Delta 1 \mathrm{mmol} / 1)\end{array}\end{array}$ & 1.24 & $1.00-1.55$ & $=0.05$ \\
$\begin{array}{l}\text { Creatinine } \\
(\Delta 10 \mu \mathrm{mol} / 1)\end{array}$ & 1.39 & $1.01-1.92$ & $<0.05$ \\
$\begin{array}{l}\text { II vs DD + ID } \\
\text { genotype }\end{array}$ & 0.27 & $1.03-1.12$ & $<0.001$ \\
\hline
\end{tabular}

$\mathrm{CI}$, Confidence interval

tients with DD or ID genotype suggests an activation of the renin-angiotensin system, which might play a role in the pathogenesis of CHD as suggested previously $[7,8,20-22]$. In patients with diabetic nephropathy, thus considered at high risk of CHD, logistic regression analysis revealed that, despite the presence of numerous well-known risk factors for CHD, and in particular modifiable factors such as hypertension and serum lipids, the II-genotype seems to act as an independent protective factor against $\mathrm{CHD}$ as compared to the DD and ID genotypes. Absence of a similar association in patients with normoalbuminuria might be due to the small number of patients with CHD in this group. No association between genotypes (II, ID, DD) and various cardiovascular risk factors was found, apart from the unexpected and unexplained finding that normoalbuminuric patients with DD genotype had lower diastolic blood pressure than normoalbuminuric patients with II or ID genotype. Blood pressure and hypertension have not been related to $\mathrm{ACE} / \mathrm{ID}$ polymorphism in previous studies of non-diabetic subjects [7, 23].

The genotype distributions in nephropathic and normoalbuminuric patients in our study were in accordance with the genotype frequencies found in the Étude Cas-Témoin de l'Infarctus du Myocarde (ECTIM) control group (0.54/0.46, D/I-allele frequency)[7] and in 150 non-diabetic patients measured in the Danish part of the MONICA study (0.55/0.45, D/ 
I-allele frequency) (personal communication, T.Hansen, Steno Diabetes Center). Plasma concentration of ACE was related to the genotype [6] and was raised in the nephropathic IDDM patients, as demonstrated previously [24].

Our findings are complementary to the original studies in non-diabetic patients [7] and NIDDM patients [8], and confirm and extend the findings of Nomura et al. [25], who in 175 Japanese patients on haemodialysis (46 patients with diabetic nephropathy) found that 4 of $30(13 \%), 4$ of $64(6 \%)$, and none of 81 patients with DD, ID and II genotypes, respectively, had a history of myocardial infarction. The prevalence of the I-allele is much higher $(64 \%)$ in the Japanese population than in Caucasians (approximately $46 \%$ ) [7].

Ruiz et al.[8] studied 132 patients with NIDDM with either myocardial infarction or severe coronary stenosis verified by coronary angiography, and 184 NIDDM patients with no history of CHD. They found a significant association between the DDgenotype and myocardial infarction or severe coronary stenosis, odds ratio 1.83 .

Originally, Cambien et al.[7] found the DD genotype to be a potent risk factor for myocardial infarction in Caucasian men, aged 25-64 in the ECTIM study. The overall increase in risk was modest, with an odds ratio of 1.34 in patients with the DD genotype. But when a subgroup analysis was carried out in a low risk group of patients with BMI less than 26 $\mathrm{kg} / \mathrm{m}^{2}$ and ApoB level less than $125 \mathrm{mg} / \mathrm{dl}$ the DD genotype assumed much greater importance, with an odds ratio of 3.2. In the corresponding high risk group the ACE/ID polymorphism does not seem to be associated to myocardial infarction, odds ratio 1.1 (NS).

Apart from coronary artery disease the ACE/ID polymorphism has recently been associated with left ventricular hypertrophy and also with hypertrophic, ischaemic or idiopathic dilated cardiomyopathy $[9$, $10,26]$. Thus, the ACE/ID polymorphism is involved in two entirely different clinical disorders - CHD and primary cardiomyopathy. The ACE/ID polymorphism might exert its pathogenic effect through variation in plasma $\mathrm{ACE}$ concentration. As demonstrated by Rigat et al.[6] plasma ACE levels in DDsubjects were twice that of II-subjects with ID-subjects having intermediate levels. Half of this phenotypic variance could be accounted for by the polymorphism, probably through a tight linkage to a nearby functional locus. A similar association was found in the present study. Another pathogenic factor was investigated by Alderman et al.[20], who reported an association between plasma renin activity and risk of myocardial infarction - but the findings have been challenged in normotensive subjects [27]. Moreover, the effect of the renin-angiotensin system need not entirely be through activation of plasma systems, but also through activation of local tissue renin systems in the heart and arteries implicated in regulation of arterial tonus, vascular smooth muscle cell proliferation and cardiac myocyte hypertrophy [21]. Perhaps pharmacological intervention with, e.g., ACE inhibitors, which has proven effective in reducing morbidity and mortality after myocardial infarction and in congestive heart failure [28-30], acts through modification of expression of this genetic risk factor.

It has been suggested, that the ACE/ID polymorphism is associated not only with risk of developing CHD and cardiomyopathy, but also with prognosis in these conditions $[9,31,32]$. An increased early mortality associated with the DD-genotype could explain the lack of association between myocardial infarction and DD genotype in the high risk groups studied by Cambien et al. [7] and Bøhn et al. [33]. This suggestion is supported by two independent studies of parental history of fatal and/or early myocardial infarction, indicating that the DD genotype is associated with an increased risk of both $[22,34]$, and by a case-control study of fatal cases of definite and possible myocardial infarction, which has documented that the insertion polymorphism is a risk factor for fatal myocardial infarction and sudden death [32].

If the death rate of $\mathrm{DD}$ individuals was increased in a population, a selective decrease in frequency of the DD-genotype with increasing age would be expected, as demonstrated in a group of severely hypertensive patients by Morris et al.[35]. This phenomenon was not present in the normotensive control group of their study. In our study no difference in genotype distribution was observed between the oldest tertile as compared to the youngest tertile of either the nephropathic or the normoalbuminuric patients. Furthermore, the distribution of the ACE/ID genotypes in diabetic patients and control subjects in our study was in Hardy-Weinberg equilibrium. Since we found no evidence suggesting that the ACE/ID polymorphism is involved in the pathogenesis of diabetic nephropathy [36], we assume that the ACE/ID polymorphism does not play a role in selection of patients progressing from microalbuminuria to overt nephropathy. Thus, these findings do not suggest a preferential loss of DD individuals in our high-risk patients with diabetic nephropathy.

We suggest that ACE/ID polymorphism may influence the frequency of life-threatening cardiac complications in IDDM patients suffering from diabetic nephropathy, a condition characterized by increased plasma ACE concentration.

Acknowledgements. We acknowledge the assistance of Ms. B. R. Jensen, Ms. U.M. Smidt and Ms. F. Savoie in conducting this study. 


\section{References}

1. Andersen AR, Christiansen JS, Andersen JK, Kreiner S, Deckert T (1983) Diabetic nephropathy in Type 1 (insulindependent) diabetes: an epidemiological study. Diabetologia 25: 496-501

2. Borch-Johnsen K, Kreiner S (1987) Proteinuria: value as predictor of cardiovascular mortality in insulin dependent diabetes mellitus. BMJ 294: 1651-1654

3. Jensen T, Stender S, Deckert T (1988) Abnormalities in plasma concentrations of lipoproteins and fibrinogen in type 1 (insulin- dependent) diabetic patients with increased urinary albumin excretion. Diabetologia 31: 142-145

4. Hallab M, Bled F, Ebran JM et al. (1992) Elevated serum angiotensin I converting enzyme activity in type I, insulindependent diabetic subjects with persistent microalbuminuria. Acta Diabetol 29: 82-85

5. van Dyk J, Erman A, Erman F, Chen-Gal B, Sulkes J, Boner $G$ (1994) Increased serum angiotensin converting enzyme activity in type I insulin-dependent diabetes mellitus: its relation to metabolic control and diabetic complications. Eur J Clin Invest 24: 463-467

6. Rigat B, Hubert C, Alhenc-Gelas F, Cambien F, Corvol P, Soubrier F (1990) An insertion/deletion polymorphism in angiotensin I converting enzyme gene accounting for half the variance of serum enzyme levels. J Clin Invest 86: 1343-1346

7. Cambien F, Poirier O, Lecerf L et al. (1992) Deletion polymorphism in the gene for angiotensin-converting enzyme is a potent risk factor for myocardial infarction. Nature 359: 641-644

8. Ruiz J, Blanché $H$, Cohen $N$ et al. (1994) Insertion/deletion polymorphism of the angiotensin-converting enzyme gene is strongly associated with coronary heart disease in non-insulin-dependent diabetes mellitus. Proc Natl Acad Sci 91: 3662-3665

9. Marian AJ, Yu Q-T, Workman R, Greve G, Roberts R (1993) Angiotensin-converting enzyme polymorphism in hypertrophic cardiomyopathy and sudden cardiac death. Lancet 342: 1085-1086

10. Raynolds MV, Bristow MR, Bush EW et al. (1993) Angiotensin-converting enzyme DD genotype in patients with ischaemic or idiopathic dilated cardiomyopathy. Lancet 342: 1073-1075

11. Parving $\mathrm{H}-\mathrm{H}$, Andersen AR, Smidt UM, Svendsen PAa (1983) Early aggressive antihypertensive treatment reduces rate of decline in kidney function in diabetic nephropathy. Lancet i:1175-1179

12. Danilov S, Jaspard E, Churakova T et al. (1994) Structure function analysis of angiotensin I converting enzyme using monoclonal antibodies. J Biol Chem 269(43):26806-26814

13. Sambrook J, Fritsch EF, Maniatis T (1991) Molecular cloning: A laboratory manual. 2nd edn. Cold Spring Harbor Laboratory Press, Plainview, New York

14. Rigat B, Hubert C, Corvol P, Soubrier F (1992) PCR detection of the insertion/deletion polymorphism of the human angiotensin converting enzyme gene (DCP 1) (dipeptidylcarboxy peptidose 1). Nucleic Acids Res 20: 1433

15. Rose GA, Blackburn H (1968) Cardiovascular survey methods. 1st edn. World Health Organization, Geneva, pp 1-188

16. Blackburn H, Keys A, Sominson E, Rautaharju P, Punsar $S$ (1960) The electrocardiogram in population studies: a classification system. Circulation 21: 1160-1175

17. Rose GA (1962) The diagnosis of ischaemic heart pain and intermittent claudication in field surveys. Bull WHO 27 : $645-658$
18. Feldt-Rasmussen B, Dinesen B, Deckert M (1985) Enzyme immunoassay: an improved determination of urinary albumin in diabetics with incipient nephropathy. Scand J Clin Lab Invest 45: 539-544

19. Katterman R, Jaworek D, Möller G (1984) Multicenter study of a new enzymatic method of cholesterol determination. J Clin Chem Biochem 22: 245-251

20. Alderman MH, Madhavan S, Ooi WL, Cohen H, Sealey JE, Laragh JH (1991) Association of the renin-sodium profile with the risk of myocardial infarction in patients with hypertension. N Engl J Med 324: 1098-1104

21. Schelling P, Fischer H, Ganten D (1991) Angiotensin and cell growth: a link to cardiovascular hypertrophy. J Hypertens $9:$ 3-15

22. Tiret L, Kee F, Poirier O et al. (1993) Deletion polymorphism in the angiotensin-converting-enzyme is associated with a parenteral history of myocardial infarction. Lancet 341: 991-992

23. Jeunemaitre $X$, Lifton RP, Hunt SC, Williams RR, Lalouel $\mathrm{J}-\mathrm{M}$ (1992) Absence of linkage between the angiotensin converting enzyme locus and human essential hypertension. Nature 1: 72-75

24. Marre M, Bernadet P, Gallois Y et al. (1994) Relationships between angiotensin I converting enzyme gene polymorphism, plasma levels, and diabetic retinal and renal complications. Diabetes 43: 384-388

25. Nomura H, Koni I, Michishita Y, Morise T, Takeda R (1994) Angiotensin-converting enzyme gene polymorphism in haemodialysis patients. Lancet $343: 482-483$

26. Schunkert H, Hense H-W, Holmer SR et al. (1994) Association between a deletion polymorphism of the angiotensin-converting-enzyme gene and left ventricular hypertrophy. N Engl J Med 330: 1634-1638

27. Meade TW, Cooper JA, Peart WS (1993) Plasma renin activity and ischemic heart disease. N Engl J Med 329: 616-619

28. Pfeffer MA, Braunwald E, Moyé LA et al. (1992) Effect of captopril on mortality and morbidity in patients with left ventricular dysfunction after myocardial infarction. $\mathbf{N}$ Engl J Med 327: 669-677

29. Yusuf S, Pepine CJ, Garces C et al. (1992) Effect of enalapril on myocardial infarction and unstable angina in patients with low ejection fractions. Lancet 340: 1173-1178

30. The Acute Infarction Ramipril Efficacy (AIRE) Study Investigators (1993) Effect of ramipril on mortality and morbidity of survivors of acute myocardial infarction with clinical evidence of heart failure. Lancet 342: 821-828

31. Ohishi M, Fujii K, Minamino T et al. (1993) A potent genetic risk factor for restenosis. Nature 5: 324-325

32. Evans A, Poirier O, Kee F et al. (1994) Polymorphisms of the angiotensin-converting-enzyme gene in subjects who died from coronary heart disease. Q J Med 87: 211-214

33. Bohn M, Berge KE, Bakken A, Erikssen J, Berg K (1993) Insertion/deletion (I/D) polymorphism at the locus for angiotensin I- converting enzyme and myocardial infarction. Clin Genetics 44: 292-297

34. Bohn M, Berge KE, Bakken A, Erikssen J, Berg K (1993) Insertion/seletion (I/D) polymorphism at the locus for angiotensin I- converting enzyme and parental history of myocardial infarction. Clin Genetics 44: 298-301

35. Morris BJ, Zee RYL, Schrader AP (1994) Different frequencies of angiotensin-converting enzyme genotypes in older hypertensive individuals. J Clin Invest 94: 1085-1089

36. Tarnow L, Cambien F, Rossing P et al. (1995) Lack of relationship between an insertion/deletion polymorphism in the angiotensin- I-converting enzyme gene and diabetic nephropathy and proliferative retinopathy in IDDM patients. Diabetes 